Marquette University

e-Publications@Marquette

Theology Faculty Research and Publications

Theology, Department of

$2-1-2000$

\title{
Melchizedek Legend of 2 (Slavonic) Enoch
}

Andrei Orlov

Marquette University, andrei.orlov@marquette.edu

Accepted version. Journal for the Study of Judaism, Vol. 31, No. 1 (2000): 23-38. DOI: (C) 2000 Brill. Used with permission. 


\title{
Melchizedek Legend of 2 (Slavonic) Enoch
}

\author{
Andrei A. Orlov \\ Theology Department, Marquette University \\ Milwaukee, WI
}

Contemporary scholarship does not furnish a consensus concerning the possible provenance of 2 (Slavonic) Enoch..$^{1}$ In the context of the ambiguity and uncertainty about the cultural and theological origins of 2 Enoch, even distant voices of certain theological themes in the text become very important. One of these important theological reminiscences of 2 Enoch is the theme of Melchizedek-the legendary priest of God Most High. ${ }^{2}$

Before giving an exposition of the content of the story it is worth mentioning that for a long time the legend was considered to be an interpolation in the text of 2 Enoch. Charles, Morfill, and Bonwetsch ${ }^{3}$ thought that the theme of Melchizedek was a sort of appendix and did not belong to the main body of the text. For this reason, the legend was not investigated for a long time. Even Fred Horton in his fundamental work dedicated to the Melchizedek tradition ignores the material of 2 Enoch on the basis that it is found only in one recension. ${ }^{4}$ On the contrary to these opinions, A. Vaillant successfully demonstrates that Melchizedek's legend is an integral part of 2 Enoch. F. Andersen supports this position. His new collation of manuscripts shows that the Melchizedek tradition is found in both recensions, in six manuscripts which represent four text families. His final conclusion is that "there is no evidence that the second part ever existed separately." 
NOT THE PUBLISHED VERSION; this is the author's final, peer-reviewed manuscript. The published version may be accessed by following the link in the citation at the bottom of the page.

\section{Exposition}

The Melchizedek narrative occupies the last chapters of the book. The content of the story is connected with the family of $\mathrm{Nir}^{6}{ }^{6}$ the priest, who is pictured in the book as "second son of Lamekh"7 and the brother of Noah. Sothonim8 the wife of Nir, gave birth to a child "in her old age," right "on the day of her death."10 She conceived the child, "being sterile" and "without having slept with her husband."11 The book narrates that Nir the priest had not slept with her from the day that the Lord had appointed him in front of the face of the people. Therefore, Sothonim hid herself during all the days of her pregnancy. ${ }^{12}$ Finally, when she was at the day of birth, Nir remembered his wife and called her to himself in the temple. She came to him and he saw that she was pregnant. Nir, filled with shame, wanted to cast her from him, but she died at his feet. Melchizedek ${ }^{13}$ was born from Sothonim's corpse. When Nir and Noah came in to bury Sothonim, they saw the child sitting beside the corpse with "his clothing on him." According to the story they were terrified because the child was fully developed physically. The child spoke with his lips and he blessed the Lord. It is of great significance that the newborn child was marked by the sign of priesthood. The story describes how "the badge of priesthood"14 was on his chest, and it was glorious in appearance. Nir and Noah dressed the child in the garments of priesthood and they fed him the holy bread. They decided to hide him, fearing that the people would have him put to death. Finally, the Lord commanded His archangel Gabriel ${ }^{15}$ to take the child and place him ${ }^{16}$ in "the paradise Eden" so that he might become the high priest after the Flood. Final passages of the short recension describe the ascent of Melchizedek on the wings of Gabriel to the paradise Eden.

\section{Shem Traditions}

The Melchizedek narrative in the book is connected with the name of Noah, the legendary pre-deluge patriarch. We can not only find Noah in the book but also his grandfather, Methuselah ${ }^{17}$ and his father, Lamech. The midrashim of these descendants of Enoch occupy chapters 68-73 of the text. Right after Enoch's ascension to the highest heaven, the firstborn son of Enoch, Methuselah, and his brothers, "the sons of Enoch," constructed an altar at Achuzan, ${ }^{18}$ the 
place where Enoch had been taken up (ch. 68). It is important to stress that the term Achuzan here is a specific name for the hill of the Temple in Jerusalem. In chapter 69 the Lord appeared to Methuselah in a night vision and appointed him as the priest before the people. Verses 11-16 of this chapter describe the first animal sacrifice of Methuselah on the altar. Chapter 70 reveals the last days of Methuselah on the earth before his death. The Lord again appeared to Methuselah in a night vision and commanded him to pass his priesthood duties on to the second son of his son Lamech-Nir. The text does not explain why the Lord wanted to pass on the priesthood to Nir instead of Noah -Lamech's firstborn son. The text just mentions that the people answered on that request, "Let it be so for us, and let the word of the Lord be just as he said to you." Further the book narrates that Methuselah invested Nir with the vestments of priesthood in front of the face of all the people and "made him stand at the head of altar."19

As shown, 2 Enoch presents Melchizedek as a continuation of the priestly line from Methuselah, son of Enoch, directly to the second son of Lamech, Nir (brother of Noah), and on to Melchizedek. 2 Enoch therefore considers Melchizedek as the grandson of Lamech. This understanding of Melchizedek as the continuation of the priestly line of descendants of Enoch has interesting parallels in rabbinic literature.

In the Babylonian Talmud the following passage is found:

R. Zechariah said on R. Ishmael's authority: The Holy One, blessed be He, intended to bring forth the priesthood from Shem, as it is written, 'And he [Melchizedek] was the priest of the most high God' (Gen 14:18). But because he gave precedence in his blessing to Abraham over God, He brought it forth from Abraham; as it is written, 'And he blessed him and said, Blessed be Abram of the most high God, possessor of heaven and earth, and blessed be the most high God' (Gen 14:19). Said Abraham to him, 'Is the blessing of a servant to be given precedence over that of his master?' Straightway it [the priesthood] was given to Abraham, as it is written (Ps 110:1), 'The Lord said unto my Lord, Sit thou at my right hand, until I make thine enemies thy footstool;' which is followed by, 'The Lord hath sworn, and will not repent, Thou art a priest forever, after the order of Melchizedek' (Ps 110:4), meaning, 'because of the word of Melchizedek.' Hence it is written, And he was a priest of the most High God, [implying that] he was a priest, but not his seed ( $b$. Ned. $32 b){ }^{20}$ 
This identification of Melchizedek with Shem, son of Noah, descendant of Methuselah and Lamech by Rabbi Ishmael ben Elisha was very popular in rabbinic literature. ${ }^{21}$ We can find the origins of the tradition from a very early time; identifying Melchizedek as Shem can be found in the Targums, ${ }^{22}$ Aramaic renderings of the Hebrew Bible. Tg. Neof. on Gen 14:18 shows the exegetical development of this identification: "And Melchisedech, king of Jerusalem-he is Shem the Great-brought out bread and wine, for he was the priest who ministered in the high priesthood before the most High God."23 The Tg. Ps. -J. holds a similar exegetical position when it reads: "... the righteous king-that is Shem, the son of Noah-king of Jerusalem, went out to meet Abram, and brought him bread and wine; at that time he was ministering before God Most High."24 Biblical chronology proves the possibility of the meeting of Shem (Melchizedek) and Abraham after the defeat of the kings (Gen 14:17). According to Gen 11:10-26, Shem lived 500 years after the birth of his first son Arphaxad. There were 290 years between the birth of Arphaxad and the birth of Abram. When Abram was born, Shem lived for another 210 years. According to Gen 25:7 Abraham lived 175 years. Therefore Shem in fact outlived Abraham by 35 years.

Another important point in identification of Shem and Melchizedek is the fact that the blessing of Shem in Gen 9:26 has distinct parallels with the blessing which Melchizedek gives to Abraham. Fred Horton proves that both blessings have some similarities from "a form-critical standpoint." 25

It is interesting to note several important similarities between targumic and rabbinic material and Melchizedek's portion of 2 Enoch.

a. 2 Enoch as well as targumic and rabbinic sources tried to put the genealogy of Melchizedek into the Semitic context of Enoch's descendants. They endeavored to give this abstract and ahistorical character of Genesis a certain historical location and place him in the context of the pre-Deluge generation.

b. Both traditions are interested in the descriptions of the priestly functions of Enoch's family. ${ }^{26} 2$ Enoch has a lengthy account of Methuselah and Nir with elaborate descriptions of their priestly and sacrificial duties and practices. As Rubinstein notes, "it is hard to escape the impression that the purpose of the account is 
to build up the priestly antecedents of Melchizedek."27 The main point of the passage from $b$. Ned. as well as from Gen. Rab. and Pirke R. El. is the building up of the priestly antecedents of Melchizedek (Shem) in the context of the transmission of this priestly line to Abraham.

c. Both traditions are also interested in taking away the priestly line from Enoch's historical descendants. $b$. Ned. 32b stressed about Shem-Melchizedek, "he was priest; but not his seed." Melchizedek's final translation to heaven at the end of 2 Enoch also shows discontinuation of the historical priestly line of Enoch's relatives. In the text, the Lord says: "Melchizedek will be my priest to all priests, ${ }^{28}$ and I will sanctify him and I will change him into a great people who will sanctify me.... Melchizedek will be the head of the priests in another generation." 29

d. Another important point, which can be found in observations of the rabbinic and 2 Enoch sources, is that the text of the Slavonic Enoch attempts to build an alternative to the traditional rabbinic line from Methuselah's priestly vocation, which can be some type of parallel to the official Noah-Shem line. The important theological role in this shift is played by previously unknown Nir, the young brother of Noah. ${ }^{30}$

We can see some sort of theological polemic by the author of 2 Enoch with traditional Judaic (targumic, rabbinic) positions. It shows that the traditional Judaic settings of the Oral Torah about Melchizedek as Shem were very important and authoritative for the audience of 2 Enoch even in the situation of their rejection.

\section{Noachic Traditions}

Our previous analysis of Shem traditions in the Melchizedek story reveals also some references to the Noachic tradition. ${ }^{31} \mathrm{~A}$ substitution of the line Noah-Shem for the line Nir-Melchizedek shows that one of the main targets of the author's polemic in 2 Enoch is in fact a Noah figure. It is not a coincidence that this sort of polemic takes place in the Enochic narrative. From the earliest Enochic materials we can see the interdependence of Noachic and Enochic traditions. Kvanvig shows that in Noachic traditions Noah and Enoch 
often appear in the same roles. ${ }^{32}$ The Slavonic Enoch in many ways is a continuation of this tendency.

According to some scholars, Melchizedek's story in Slavonic Enoch recalls some parallels with the birth of Noah ${ }^{33}$ in the Genesis Apocryphon of Qumran. ${ }^{34}$ In the Qumran text, Lamech is worried about the birth of Noah, his son. Lamech suspects that his wife Bathenosh was unfaithful to him and that "the conception was (the work) of the Watchers and the pregnancy of the Holy Ones, and it belonged to the Nephil[in]." 35 The story of the relationship between Lamech and Bathenosh found in the Apocryphon is very similar to the story of the relationships between Nir and Sophonim. However, there are some essential differences between the texts. In the Qumran text the wife of Lamech, in response to his angry questions, tries to remind him of their intimacies - "Oh my brother and lord! remember my sexual pleasure... [...] in the heat of intercourse, and the gasping of my breath in my breast." ${ }^{36}$ She swears that the seed was indeed of Lamech: "I swear to you by the Great Holy One, by the King of the hea[vens...]...[...] that this seed comes from you, [...] and not from any foreigner nor from any of the watchers or sons of heav[en]."37

On the other hand, in 2 Enoch Sothonim did not explain the circumstances of the conception. She answered Nir: "O my lord! Behold, it is the time of my old age, and there was not in me any (ardor of) youth and I do not know how the indecency of my womb has been conceived." ${ }^{38}$ However, some scholars draw attention to the fact that both texts have similar features in this situation. Delcor affirms that the phrase of Lamech in the beginning of the Apocryphon, "Behold, then I thought in my heart that the conception was the work of the Watchers and the pregnancy, of the Holy Ones..." can be compared with the words of Noah in 2 Enoch spoken at the time of the examination of Melchizedek: "This is of the Lord, my brother." 39 An important supporting detail here is the fact that the description of Enoch and his descendants in Genesis Apocryphon shows a number of interesting similarities with 2 Enoch's story.

Chapters 39-66 of 2 Enoch describe the instruction which Enoch gave to his sons and the elders of the people during his thirty day visit to the earth. The text makes clear that during this visit Enoch is 
already an angelic being. In chapter 56 of 2 Enoch he says to his son: "Listen, my child! Since the time when the Lord anointed me with the ointment of my glory, it has been horrible for me, and food is not agreeable to me, and I have no desire for earthly food." 40

Chapter 67 of 2 Enoch describes the final departure of Enoch to heaven. The information about the transformed Enoch can be found also in the Genesis Apocryphon. The text says that when Methuselah knew about Lamech's suspicions he decided to ask advise from Enoch. The Genesis Apocryphon continues that "he (Methuselah) left for the higher level, to Parvaim, and there he met Enoch, [his father...]."41 This reference to the "higher level" can be considered as a hint for the elevated status of the translated Enoch. Apocryphon further says that " He (Methuselah) said to Enoch, his father: O my father and lord, to whom I have co[me...] [...] I say to you: Do not be annoyed with me because I came here to $[\ldots]$ you $[. .$.$] fear (?) before you [\ldots] .{ }^{\prime 42}$ Methuselah's fear before Enoch is an additional supporting detail that he in fact met not a man, but a heavenly being.

Another feature of 2 Enoch which shows some possible connection between this text and the sectarian Judaism is the issue of animal sacrifices. The description of animal sacrifices occupies a very important place in the narrative of 2 Enoch. In chapter 59, Enoch instructed Methuselah, his brothers-Regim, Ariim, Akhazukhan, Kharimion-and the elders of all the people how to perform animal sacrifices: "... he who brings a sacrifice of clean beasts, it is healing, he heals his soul. And he who brings a sacrifice of clean birds, it is healing, he heals his soul. And everything which you have for food, bind it by four legs ${ }^{43}$; there is healing, he heals his soul. He who puts to death any animal without binding it, it is an evil custom; he acts lawlessly with his own soul."44 Further the book tells that right after the appointment of Methuselah to the position of the priest he came up to the Lord's altar "with all the people in procession behind him and he stood in front of the altar with all the people ... around the altar ... and ... the elders of the people, ... taking sheep and oxen ... tied (their) four legs together, and placed (them) at the head of the altar." $45 \mathrm{~S}$. Pines draws attention to this unique practice of tying together four legs during animal sacrifices. He refers to a passage in the Mishna ( $m$. Tamid, 4:1) which, according to the most probable 
interpretation, states that each of the forelegs of the sacrificial animal was tied to the corresponding hind leg and declares that the tying together of all the four legs was contrary to the tradition. ${ }^{46}$ Pines gives one of the two explanations found in the Gemara of the Babli that this expression of disapproval was due to the fact that the customs of the heretics, minim, ${ }^{47}$ should not be imitated. ${ }^{48}$ The practice of tying together all four legs had very strong sectarian meaning for the authors of Mishnaic sacrificial prescriptions. In his final conclusion, Pines suggests that "it may have been an accepted rite of a sect, which repudiated the sacrificial customs prevailing in Jerusalem. It might be conjectured that this sect might have been the Essenes, whose sacrificial usage differed according to the one reading of the passage of Josephus ${ }^{49}$ from those practiced at the Temple."50

\section{Sethian Traditions}

Schlomo Pines' reference to sacrificial practices of "minim," heretics, which were usually represented in the Jewish orthodox mindset as Jewish Gnostics, ${ }^{51}$ necessitated further examination of the relationship between the Melchizedek story of 2 Enoch and some Gnostic traditions. One of the tractates of the Nag Hammadi corpus, Melchizedek (further Melch.) deserves special attention because it contains materials that echo certain motifs in 2 Enoch's story. ${ }^{52}$ The text has a form of revelations given by heavenly intermediaries to Melchizedek who communicates the revelations to a privileged few, "the congregation (e)kklhsi\&a) of [the] [children] of Seth (5:1920). ${ }^{\prime 53}$ According to scholars, Melch. has important similar features with traditions associated with Sethian gnosticism. ${ }^{54}$ It is possible that the author of the tractate reworked some earlier Judaic Melchizedek's traditions into gnostic Christian settings. ${ }^{55}$ In spite of the fragmentary character of the tractate, there are a number of important details which can be connected with Melchizedek's story in 2 Enoch. Two features of the Gnostic text are especially valuable. First, the author's use of the phrase "the children of Seth" (5:20), and second, his usage of the phrase "the [race] (ge\&nov) of the High priest (a) rxiereu\&v) (6:17)."56 These details seem to have certain parallels with Melchizedek's narrative of 2 Enoch, which contains materials about priestly functions of Seth. In chapter 72 of the shorter recension of 2 Enoch, the following statement comes from the lips of the Lord: "... 
and Melchizedek will be the head of the priests in another generation as was Seth in this generation." 57 The author's familiarity with the traditions which exalted Seth, however, become evident much earlier in chapter 33:10 where the Lord promises to give Enoch an intercessor archangel Michael and guardian angels Ariokh and Mariokh on account of his handwritings and the handwritings of his fathers-Adam and Seth. ${ }^{58}$ Mentioning all three traditions together shows that Sethian tradition has in the eyes of 2 Enoch's author equal value to the tradition of Adam and Enoch.

Melch. also gives an interesting list which includes Adam, Enoch, and Melchizedek. ${ }^{59}$ Birger Pearson suggests that "the list of biblical figures mentioned in this passage, culminating with Melchizedek, may be intended as a list of those heroes of the past who functioned as priests." 60

Another important testimony to Sethian tradition is found in chapter 71 where the author of 2 Enoch depicts a priestly line which begins with Seth: "Therefore honor him (Melchizedek) together with your servants and great priests, with Seth, and with Enoch, and Maleleil, and Aamilam, and Phrasidam, and with Maleleil, and with Rusif and with Enoch and with your servant Nir..."61

These testimonies to Sethian tradition show that there are obvious similarities between Melch. and 2 Enoch. Both stories emphasize priestly functions of Seth in their connections with priestly functions of Melchizedek. It is noteworthy that this emphasis on priestly role of Seth is a rare motif in Sethian traditions. In the variety of Sethian traditions, Seth is often pictured as an astrologer, a scribe, or the head of a generation, but he is rarely viewed as a priest. ${ }^{62}$

From the other side, despite these parallels, ${ }^{63}$ there is a fundamental divergence between Melch. and 2 Enoch. The purpose of the author of Melch. is apparent-to place Melchizedek in the context of Sethian priestly authority. In observations on the tractate, B. Pearson stresses that because of the reference to the "children of Seth" (5:20), and the parallel reference to the "race of the high priest" (i.e. Melch. 6:17), it is possible that in Melch., the priest-savior Melchizedek is regarded as an earthly incarnation of the heavenly 
Seth. ${ }^{64}$ On the contrary, in 2 Enoch, however, there is an established attempt to challenge the Sethian priestly line and replace it with a new postdiluvian priestly authority of Melchizedek.

\section{Conclusion}

The fragmentary character of our observations about the Melchizedek legend does not allow for the complete picture of the possible cultural, historical, or theological provenance of Melchizedek's story in 2 Enoch to be considered. However, some conclusions can be made at this stage of the research. These conclusions focus on the problem of the hypothetical community behind the Melchizedek narrative.

First, the Melchizedek portion demonstrates the interest in the issues of priestly practice, succession and authority, which occupy an important part in the eschatology of 2 Enoch.

Second, the material reflects complicated polemics with various traditions of priestly practice and the priestly succession inside Judaism.

Third, the story of Melchizedek, this sacerdos in aeternum, is used in 2 Enoch as well as in many other traditions as the theological tool of legitimization of alternative priestly authority (line).

Fourth, it is possible that in the text we can see a specific attitude toward the priestly authority (hierocracy) connected with the Temple in Jerusalem. ${ }^{65}$ The important supporting detail here is naming the place of sacrificial duties of Enoch's descendants as Achuzan. ${ }^{66}$ This may also be the main reason for the replacement of official priestly line Noah-Shem to the line Nir-Melchizedek, as a legitimate background for the new sectarian priestly authority.

Fifth, the Melchizedek material of 2 Enoch was probably composed in a community which respected the authority of the Jewish lore (the opinion about Enoch's ancestors as predecessors of Melchizedek). This community might have had certain liturgical and theological differences (sectarian biases) from the mainstream of Second Temple Judaism. 
Sixth, the community of 2 Enoch apparently repudiated the sacrificial customs prevailing in traditional Judaism (Jerusalem) (the tying together of all the four legs of the animals during the sacrifices).

Seventh, liturgical (priesthood line) and exegetical (Noah, Melchizedek) features of the Melchizedek portion of 2 Enoch have certain similarities to the ideology of the Qumran community (an alternative priestly line, exegesis of Noah, and Melchizedek's story). It is evident, however, that the ideological and theological settings of the document cannot be explained solely by referring to the Qumran materials because of an absence of major Judaic symbols and themes which occupied a central place in the ideology of the Qumranites.

\section{Notes}

${ }^{1}$ On different approaches to 2 Enoch see: I. D. Amusin, Kumranskaja Obshchina (Moscow: Nauka, 1983); F. Andersen, "2 (Slavonic Apocalypse of) Enoch," The Old Testament Pseudepigrapha (2 vols.; ed. J. H. Charlesworth; New York: Doubleday, 1985 [1983]) 1.91-221; G. N. Bonwetsch, Das slavische Henochbuch (AGWG, 1; Berlin: Weidmannsche Buchhandlung, 1896); idem, Die Bücher der Geheimnisse Henochs: Das sogenannte slavische Henochbuch (TU, 44; Leipzig, 1922); C. Böttrich, Weltweisheit, Menschheitsethik, Urkult: Studien zum slavischen Henochbuch (WUNT, 2/50; Tübingen: Mohr/Siebeck, 1992); idem, Das slavische Henochbuch (JSHRZ, 5; Gütersloh: Gütersloher Verlaghaus, 1995); idem, Adam als Mikrokosmos: eine Untersuchung zum slavischen Henochbuch (Judentum und Umwelt, 59; Frankfurt am Main: Peter Lang, 1995); R. H. Charles, and W. R. Morfill, The Book of the Secrets of Enoch (Oxford: Clarendon Press, 1896); J. H. Charlesworth, "The SNTS Pseudepigrapha Seminars at Tübingen and Paris on the Books of Enoch (Seminar Report)," NTS 25 (1979) 315-23; J. H. Charlesworth, The Old Testament Pseudepigrapha and the New Testament. Prolegomena for the Study of Christian Origins (SNTSMS, 54; Cambridge: Cambridge University Press, 1985); J. Collins, "The Genre of Apocalypse in Hellenistic Judaism," Apocalypticism in the Mediterranean World and the Near East (ed. D. Hellholm; Tübingen: Mohr/Siebeck, 1983); L. Cry, "Quelques noms d'anges ou d'êtres mystérieux en II Hénoch," RB 49 (1940) 195-203; U. Fischer, Eschatologie und Jenseitserwartung im hellenistischen

Journal for the Study of Judaism, Vol. 31 (2000): pg. 23-38. DOI. This article is (C) Brill Academic Publishers and permission has been granted for this version to appear in e-Publications@Marquette. Brill Academic Publishers does not grant permission for this article to be further copied/distributed or hosted elsewhere without the express permission from Brill Academic Publishers. 
Diasporajudentum (BZNW, 44; Berlin: W. de Gruyter, 1978); A. S. D. Maunder, "The Date and Place of Writing of the Slavonic Book of Enoch," The Observatory 41 (1918) 309-316; N. Meshcherskij, "Sledy pamjatnikov Kumrana v staroslavjanskoj i drevnerusskoj literature ( $\mathrm{K}$ izucheniju slavjanskih versij knigi Enoha)," Trudy otdela drevnerusskoj literatury 19 (1963) 130-47; idem, "K voprosu ob istochnikah slavjanskoj knigi Enoha," Kratkie soobshchenija Instituta narodov Azii 86 (1965) 72-8; J. T. Milik, The Books of Enoch: Aramaic Fragments of Qumran Cave 4 (Oxford: Clarendon Press, 1976); H. Odeberg, 3 Enoch or the Hebrew Book of Enoch (New York: KTAV, 1973); A. Orlov, "The Origin of the Name 'Metatron' and the Text of 2 (Slavonic Apocalypse of) Enoch," JSP 21 (2000) 19-26; idem, "Titles of Enoch-Metatron in 2 Enoch," JSP 18 (1998) 71-86; S. Pines, "Eschatology and the Concept of Time in the Slavonic Book of Enoch," Types of Redemption (eds. R. J. Zwi Werblowsky and C. Jouco Bleeker; SHR, 18; Leiden: Brill, 1970), 72-87; A. Rubinstein, "Observations on the Slavonic Book of Enoch," JJS 15 (1962) 1-21; P. Sacchi, Jewish Apocalyptic and its History (JSPSS, 20; Sheffield: Sheffield Academic Press, 1996); A. De Santos Otero, "Libro de los secretos de Henoc (Henoc eslavo)," Apócrifos del Antiguo Testamento (4 vols.; ed. A. Díez Macho; Madrid: Ediciones Christiandad, 1984), 4.147-202; G. Scholem, Jewish Gnosticism, Merkabah Mysticism and Talmudic Tradition (New York: Jewish Theological Seminary of America, 1965); M. I. Sokolov, "Materialy i zametki po starinnoj slavjanskoj literature. Vypusk tretij, VII. Slavjanskaja Kniga Enoha Pravednogo. Teksty, latinskij perevod i izsledovanie. Posmertnyj trud avtora prigotovil k izdaniju M. Speranskij," Chtenija v Obshchestve Istorii i Drevnostej Rossijskih (COIDR) 4 (1910), 1-167; M. Stone, Jewish Writings of the Second Temple Period (2 vols; CRINT, 2.2; Assen Van Gorcum/Philadelphia: Fortress Press, 1984), 2, 406-8; A. Vaillant, Le livre des secrets d'Hénoch: Texte slave et traduction française (Paris: Institut d'Etudes Slaves, 1952; repr. Paris, 1976); J. VanderKam, Enoch: A Man for All Generations (Columbia: University of South Carolina, 1995).

2 On Melchizedek traditions and Melchizedek in 2 Enoch see: I. Amusin, "Novyj eshatologicheskij tekst iz Kumrana (11QMelchizedek)," Vestnik Drevnej Istorii 3 (1967) 45-62; idem, Teksty Kumrana (Pamjatniki pis'mennosti vostoka, 33/1; Moscow: Nauka, 1971); V. Aptowitzer, "Malkizedek. Zu den Sagen der Agada," Monatschrift für Geschichte und Wissenschaft des Judentums 70 (1926) 93-113; A. 
Caquot, "La pérennité du sacerdoce," Paganisme, Judaïsme, Christianisme (Paris: E. De Boccard, 1978), 109-16; M. De Jonge and A. S. Van der Woude, "11QMelchizedek and the New Testament," NTS 12 (1965-6) 301-26; M. Delcor, "Melchizedek from Genesis to the Qumran texts and the Epistle to the Hebrews," JSJ 2 (1971) 115-35; F. du Toit Laubscher, "God's Angel of Truth and Melchizedek. A note on 11 Q Melh 13b," JSJ (1972) 46-51; J. Fitzmyer, "Further Light on Melchizedek from Qumran Cave 11," Essays on the Semitic Background of the New Testament (SBLSBS, 5; Missoula, MT: Scholars Press, 1974), 245-67; J. Gammie, "Loci of the Melchizedek Tradition of Gen. 14:18-20," JBL 90 (1971) 385-96; F. García Martínez, "4Q Amram B 1:14; ¿Melkiresa o Melki-sedeq?" RevQ 12 (1985) 111-14; C. Gianotto, Melchizedek e la sua tipologia: Tradizioni giudiche, cristiane e gnostiche (sec II a.C.-sec.III d.C) (SrivB, 12; Brescia: Paideia, 1984); I. Gruenwald, "The Messianic Image of Melchizedek," Mahanayim 124 (1970) 88-98 (in Hebrew); F. Horton, The Melchizedek Tradition: A Critical Examination of the Sources to the Fifth Century A.D. and in the Epistle to the Hebrews (SNTSMS, 30; Cambridge/London/New York/Melbourne: Cambridge University, 1976); P. Kobelski, Melchizedek and Melchirešac (CBQMS, 10; Washington: The Catholic Biblical Association of America, 1981); 0. Michel, "Melchizedek," TDNT 4.568-71; B. Pearson, "The Figure of Melchizedek in the First Tractate of the Unpublished Coptic-Gnostic Codex IX from Nag Hammadi," Proceedings of the XIIth International Congress of the International Association for the History of Religion (Supplements to Numen, 31; Leiden: Brill, 1975), 200-8; B. Pearson, Gnosticism, Judaism and Egyptian Christianity (Minneapolis: Fortress Press, 1990); J. Petuchowski, "The Controversial Figure of Melchizedek," HUCA 28 (1957) 127-36; H. Rowley, "Melchizedek and Zadok (Gen 14 and Ps 110)," Festschrift für Alfred Bertholet zum 80. Geburtstag (Tübingen: Mohr/Siebeck, 1950), 461-72; M. Simon, "Melchisédech dans la polémique entre juifs et chrétiens et dans la légende," Revue d'Histoire et de Philosophie Religieuses (1937) 58-93; R. Smith, "Abram and Melchizedek (Gen. 14, 18-20)," Zeitschrift für die Alttestamentliche Wissenschaft LXXXVII (1965), 129-53; H. Stork, Die sogenannten Melchizedekianer mit Untersuchungen ihrer Quellen auf Gedankengehalt und dogmengeschichtliche Entwicklung (Forschungen zur Geschichte des neutestamentlichen Kanons und der altkirchlichen Literatur, 8/2; Leipzig: A. Deichert, 1928); G. Vajda, 
"Melchisédec dans la mythologie ismaélienne," Journal Asiatique 234 (1943-1945) 173-83; G. Wuttke, Melchisedech der Priesterkönig von Salem: Eine Studie zur Geschichte der Exegese (BZNW, 5; Giessen: Töpelmann, 1927).

${ }^{3}$ Cf. R. H. Charles and W. R. Morfill., The Book of the Secrets of Enoch (Oxford: Clarendon Press, 1896); G. N. Bonwetsch, Das slavische Henochbuch (AGWG, 1; Berlin, 1896).

${ }^{4}$ Horton, The Melchizedek Tradition, 81.

${ }^{5}$ Andersen, 92.

${ }^{6}$ Slav. Nip. There were a number of attempts to interpret this enigmatic name. One of them was Vaillant's hypothesis that Slavonic "Nir" equals Semitic $r n$, and can be taken in its etymological sense as "light." He supports his opinion by referring to Ethiopic Enoch, since Nir, the brother of Noah, is in 2 Enoch a "dedoublement" of Noah, who was described as the wonder child in 1 Enoch 106. Vaillant, xii. Vaillant's argument probably refers to the "light-like appearence" of Noah in Ethiopic Enoch: "His eyes are like the rays of the sun, and his face glorious" (106:5). The hypothesis has many weak points. Rubinstein shows the difficulty of this explanation, because the "dedoublement" of Noah in Slavonic Enoch is related to the description of Melchizedek, not Nir (see our discussion about Noah-Melchizedek's birth). Rubinstein also stresses that there is nothing miraculous about Nir in 2 Enoch and he (Nir) can be described as a "sacerdotal drudge." Rubinstein, Observations, 17-18. Rubinstein notes a remote possibility that the name of Nir was chosen with an eye to the figurative use of the term rn in the Old Testament for the description of "dominion" of David's descendants. He further suggests that "it is not impossible that an oral exegesis of the Melchizedek legend in Slavonic Enoch somehow connected Melchizedek and Nir with Davidic descent, though the fact that Nir is only said to have adopted Melchizedek is an obvious difficulty." Rubinstein, Observations, 18. Finally, J. Milik argues that Nir "certainly means 'luminary,' because the author of 2 Enoch doubtless drew on the name of the wife of Noah, Nwri\&a, meaning 'Fire of God'." Milik, The Books of Enoch, 115. In my opinion, one more possible explanation of the name Nir can be suggested. This interpretation can be connected with the meaning of Nir as "clearing, breaking ground or earth." M. Jastrow in his dictionary defines ryn as "to break ground," "to clear." Cf. M. Jastrow, A Dictionary of the Targumim, the Talmud Babli and Yerushalmi, and the Midrashic 
Literature (New York: Judaica Press, 1985), 909. According to Jastrow it can mean "new broken land' in some instances. In 2 Enoch the destiny of Nir is connected with "clearing of the Earth." The Lord told him that He planned "to send down a great destruction on the earth." Nir is the last priest before the great destruction of the Flood. At the very end of 2 Enoch, Nir says: "For I know indeed that this race will end in confusion, and everyone will perish, except that Noah, my brother, will be preserved in that generation for procreation." Nir is indeed the man who beheld the future "clearing, breaking down" of the earth, therefore it is possible that his name reflects this coming situation.

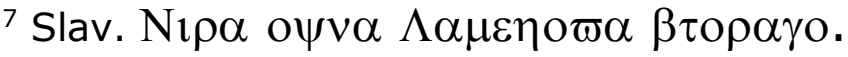

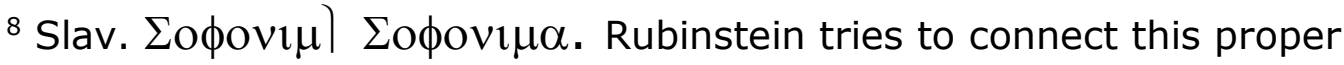
name with the facts of Sothonim's biography. He draws attention to the details of the story: Sothonim who had been described earlier as old and on the point of death, falls dead at Nir's feet and while Nir is away, having gone to inform Noah of Sothonim's death, the infant Melchizedek emerges from her body. Rubinstein believes that it is highly probable that the author of 2 Enoch had in mind the story of Benjamin's birth in Gen 35:18. Rachel travailed, and had a difficult labor and as her soul was departing ... she called his name Ben-oni..., i.e. the son of my sorrow. Rubinstein further suggests that the name Sothonim may well mean "the end of afflictions," "the end of sorrows" - in Hebrew, Mynw) Pws - symbolic of Sothonim's release from the feelings of shame and sorrow during her pregnancy and her dispute with Nir. Cf. Rubinstein, Observations, 18.

${ }^{9}$ Slav.

${ }_{10}$ Slav. $\varpi \delta \varepsilon v \mid \sigma \mu \varepsilon \rho \tau$.

${ }^{11}$ Certain parallels with the birth of Jesus were discussed by scholars. Andersen concludes that "it is certainly not an imitation of the account of Jesus' birth found in Matthew and Luke.... No Christian could have developed such a blasphemy." Andersen, 97.

12 Professor Ben Zion Wacholder in his kind letter to me suggested an interesting interpretation of the name Sothonim. He mentioned that the phonetic pattern of the name could be traced to the Hebrew word Mynwpc, hidden or mysteries. The hypothesis is supported by the fact that Sothonim hid herself from Nir during days of her pregnancy. 
NOT THE PUBLISHED VERSION; this is the author's final, peer-reviewed manuscript. The published version may be accessed by following the link in the citation at the bottom of the page.

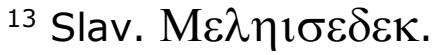

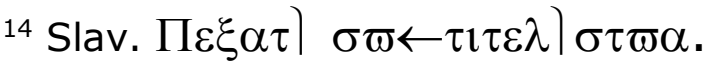

${ }^{15}$ In the longer recension - Michael,

${ }^{16}$ The preservation of Melchizedek as protection against the unrighteousness of the world reveals an interesting parallel to the Qumranic term )+\#q sdrp-"paradise of righteousness."

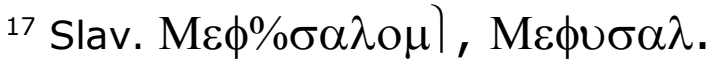

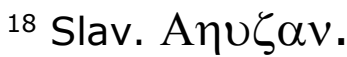

${ }^{19}$ Andersen, "2 Enoch," 197-203.

20 The Babylonian Talmud. Seder Nedarim (London: Soncino Press, 1936), 98-9.

${ }^{21}$ Two other rabbinic evidences that attest Melchizedek as Shem include Pirke R. El. and Gen. Rab. Pirke R. El. has two references to Melchizedek-Shem. The first reference occurs in the passage dedicated to the handling of the tradition of intercalation among the Patriarchs. The text says that "Noah handled on the tradition to Shem, and he was initiated in the principle of intercalation; he intercalated the years and he was called a priest, as it is said, "And Melchizedek king of Salem ... was a priest of God Most High" (Gen 14:18). Was Shem the Son of Noah a priest? But because he was the first-born, and because he ministered to his God by day and by night, therefore was he called a priest." Pirke de Rabbi Eliezer. Translated by Gerald Friedländer (New York: Hermon, 1965), 53. The second reference to MelchizedekShem in Pirke $R$. El. occurs in the chapter 28 where we can find the following passage: "Rabbi Joshua said: Abraham was the first to begin to give a tithe. He took all the tithe of the kings and all the tithe of the wealth of Lot, the son of his brother, and gave (it) to Shem, the Son of Noah, as it is said, 'And he gave him a tenth of all.'" Pirke de Rabbi Eliezer. Translated by Gerald Friedländer (New York: Hermon, 1965), 195.

Gen. Rab. gives a very interesting interpretation to the fear of Abram after his meeting with Melchizedek. It says: "Fear not, Abram. Whom did he fear? Rabbi Berekiah said: He feared Shem (whose descendants, viz. Chedorlaomer and his sons, Abraham had slain), as it is written, 'The isles saw, and feared' (Isa 41:5): just as islands stand out in the sea, so were Abraham and Shem outstanding in the world. And feared: Each one feared the other. The former (Abraham) feared the latter, thinking, perhaps he nurses resentment against me 
for slaying his sons. And the latter (Shem) feared the former, thinking, Perhaps he nurses resentment against me for begetting wicked offspring." Midrash Rabbah (10 vols.; London: Soncino Press, 1961), 1.365. This passage shows that not only was Melchizedek Shem, but the four kings of the Elamite opposition were sons of Shem.

22 Only the $T g$. Onq. does not mention Shem in connection with Melchizedek. The interesting fact here is that $\mathrm{Tg}$. Onq. is the only targum which also shows a negative attitude toward Enoch: "and Enoch walked in reverence of the Lord, then he was no more, for the Lord has caused him to die (Gen. 5,24)." B. Grossfeld (tr.), The Targum Onkelos to Genesis (Aramaic Bible, 6; Wilmington, Del.: Michael Glazier, 1988), 52.

${ }^{23}$ M. McNamara (tr.), Targum Neofiti 1: Genesis (AB, 1A; Collegeville, Minn.: Liturgical Press, 1992), 92.

24 M. Maher (tr.), Targum Pseudo-Jonathan: Genesis (AB, 1B; Collegeville, Minn.: Liturgical Press, 1992), 58.

25 Horton, 117.

26 Sacchi notes that the Melchizedek story in 2 Enoch gives "the impression of a work that develops an Enochic priestly tradition in the midst of the problems of first-century Jewish thought, with particular reference to the relation between the function of Enoch and those of Melchizedek." Cf. P. Sacchi, Jewish Apocalyptic and Its History, 234-5. 27 Rubinstein, 5.

${ }^{28}$ Andersen notices that this detail is one more piece of evidence against Christian authorship of 2 Enoch. He says that "the fantastic details about this priest conflict with Christian belief in Jesus as God's sole legitimate priest in heaven." Andersen, 96.

29 Andersen, 209.

30 This substitution of Nir for Noah could be also viewed as a polemic with Noachic tradition. See our analysis of Noachic tradition.

${ }^{31}$ On Noachic traditions see: L. Bailey, Noah: the Person and the Story in History and Tradition (Columbia, South Carolina: University of South Carolina, 1989); F. García Martínez, Qumran and Apocalyptic (STDJ, 9; Leiden: Brill, 1992), 24-44; J. Lewis, A Study of the Interpretation of Noah and the Flood in Jewish and Christian Literature (Leiden: Brill, 1968); J. Reeves, "Utnapishtim in the Book of Giants?" JBL 12 (1993) 110-15; J. VanderKam, "The Righteousness of Noah," Ideal Figures in Ancient Judaism: Profiles and Paradigms (eds. J. J. Collins and G. W. E. Nickelsburg; SBLSCS, 12; Chico: Scholars Press, 1980), 13-23; J.

Journal for the Study of Judaism, Vol. 31 (2000): pg. 23-38. DOI. This article is @ Brill Academic Publishers and permission has been granted for this version to appear in e-Publications@Marquette. Brill Academic Publishers does not grant permission for this article to be further copied/distributed or hosted elsewhere without the express permission from Brill Academic Publishers. 
VanderKam, The Birth of Noah," Intertestamental Essays in Honor of Josef Tadeusz Milik (ed. Z. J. Kapera; Qumranica Mogilanensia, 6; Krakow: The Enigma Press, 1992), 213-31.

$32 \mathrm{H}$. Kvanvig, Roots of Apocalyptic. The Mesopotamian Background of the Enoch Figure and the Son of Man (WMANT, 61; Neukirchen-Vluyn: Neukirchener Verlag, 1988), 117.

${ }^{33}$ Another similar motif in the Noachic traditions is the story of Noah's birth in 1 Enoch 106, who appears also as a marvellous child. The story in 1 Enoch 106-7 says: "And after (some) days my son Methuselah took for his son Lamech a wife, and she became pregnant by him and bore a son. And his body was white like snow and red like the flower of a rose, and the hair of his head (was) white like wool... and his eyes (were) beautiful; and when he opened his eyes, he made the whole house bright like the sun so that the whole house was exceptionally bright. And when he was taken from the hand of the midwife, he opened his mouth and spoke to the Lord of Righteousness. And his father Lamech was afraid of him and fled and went to his father Methuselah. And he said to him: 'I have begotten a strange son; he is not like a man, but is like the children of the angels of heaven, of a different type, and not like us. And his eyes (are) like the rays of the sun, and his face glorious. And it seems to me that he is not sprung from me, but from angels."' M. Knibb, The Ethiopic Book of Enoch (2 vols., Oxford: Clarendon Press, 1978) 2,244-45.

$34 \mathrm{M}$. Delcor, "Melchizedek from Genesis to the Qumran Texts and the Epistle to the Hebrews," JSJ 2 (1971) 129; G. W. E. Nickelsburg, Jewish Literature between the Bible and the Mishnah (Philadelphia: Fortress Press, 1981), 185.

${ }^{35}$ F. García Martínez and E. J. C. Tigchelaar (eds.), The Dead Sea Scrolls Study Edition (Leiden; New York; Köln: Brill, 1997), 1.29. ${ }^{36}$ F. García Martínez and E. J. C. Tigchelaar (eds.), The Dead Sea Scrolls Study Edition, 1.29.

${ }^{37}$ F. García Martínez and E. J. C. Tigchelaar (eds.), The Dead Sea Scrolls Study Edition, 1.29-31.

38 Andersen, "2 Enoch," 205.

39 Delcor, "Melchizedek from Genesis to the Qumran Texts and the Epistle to the Hebrews," 129.

${ }^{40}$ Andersen, "2 Enoch," 183.

${ }^{41}$ F. García Martínez and E. J. C. Tigchelaar (eds.), The Dead Sea Scrolls Study Edition, 1.31. 
${ }^{42}$ F. García Martínez and E. J. C. Tigchelaar (eds.), The Dead Sea Scrolls Study Edition, 1.31.

${ }^{43}$ Slav. $\sigma \varpi \leftarrow(\varepsilon \tau \varepsilon \varepsilon \pi \mathrm{o} \mid \varepsilon \tau \psi \rho \varepsilon$ vo $\gamma$ l.

${ }^{44}$ Andersen, "2 Enoch," 185.

${ }^{45}$ Andersen, "2 Enoch," 199.

${ }^{46}$ S. Pines, "Eschatology and the Concept of Time in the Slavonic Book of Enoch," Types of Redemption (eds. R. J. Zwi Werblowsky and C. Jouco Bleeker; SHR, 18; Leiden: Brill, 1970), 74-75.

${ }^{47}$ b. Tamid 31b.

${ }^{48}$ Pines, "Eschatology and the Concept of Time in the Slavonic Book of Enoch," 75.

${ }^{49}$ Ant. 18, 18.

50 Pines, "Eschatology and the Concept of Time in the Slavonic Book of Enoch," 75.

${ }^{51}$ G. Scholem, Major Trends in Jewish Mysticism (New York: Schocken, 1991), 359.

52 The issue of possible connections between the Nag Hammadi texts and the Enochic tradition can be clarified by reference to some patristic materials. As we know, the place of discovery of the Nag Hammadi library was close to the former site of the Pachomian monastery at Chenoboskion. The following condemnation of the "apocryphal books" was made by patriarch Athanasius and recorded in the Pachomian Lives: "Who has made the simple folk believe that these books belong to Enoch even though no scriptures existed before Moses?" Cit. in D. Brakke, Athanasius and the Politics of Ascetism (Oxford: Clarendon, 1995), 330.

${ }^{53}$ Birger A. Pearson (ed.), Nag Hammadi Codices IX and X (NHS, 15; Leiden: Brill, 1981), 51.

${ }^{54}$ Birger A. Pearson (ed.), Nag Hammadi Codices IX and X, 36.

${ }^{55}$ Pearson stresses the fact that Jewish apocalyptic elements are prominent in Melch. He argues that "it might be suggested that Melch. is a Jewish-Christian product containing an originally pre-Christian Melchizedek speculation overlaid with Christian christological reinterpretation." Birger A. Pearson (ed.), Nag Hammadi Codices IX and $x, 34$.

${ }^{56}$ Birger A. Pearson (ed.), Nag Hammadi Codices IX and X, 53. 57 "I Melkisedek boude glava iereem $v$ rode tom jako zhe bo mi Sif $v$ rode sem." Cf. Manuscripts [B] and [Rum] in: M. I. Sokolov, "Materialy i zametki po starinnoj slavjanskoj literature. Vypusk tretij, VII. 
Slavjanskaja Kniga Enoha Pravednogo. Teksty, latinskij perevod i izsledovanie. Posmertnyj trud avtora prigotovil k izdaniju M. Speranskij," Chtenija v Obshchestve Istorii i Drevnostej Rossijskih (COIDR) 4 (1910), 106 and 155.

58 Andersen, 157.

59 "... of Adam [Abel], Enoch, [Noah] you, Melchizedek, [the Priest] of God [Most High] (12:7-11)." Birger A. Pearson (ed.), Nag Hammadi Codices $I X$ and $X, 63$.

60 Birger A. Pearson (ed.), Nag Hammadi Codices IX and X, 25. Pearson supports his hypothesis by referring to the list of priests in the Hellenistic-Jewish synagogue prayer quoted in Const. Ap. VIII.5.3, which includes Abel, Seth, Enos, Enoch, Noah, and Melchizedek. ${ }^{61}$ Manuscript [B]. Cf. M. I. Sokolov, "Materialy i zametki po starinnoj slavjanskoj literature. Vypusk tretij, VII. Slavjanskaja Kniga Enoha Pravednogo. Teksty, latinskij perevod i izsledovanie. Posmertnyj trud avtora prigotovil k izdaniju M. Speranskij," COIDR 4 (1910), 106. ${ }^{62}$ On the figure of Seth and Sethian traditions cf. A. Klijn, Seth in Jewish, Christian and Gnostic Literature (SNT, 46; Leiden: Brill, 1977); R. Kraft, "Philo on Seth: Was Philo Aware of Traditions Which Exalted Seth and His Progeny?" The Rediscovery of Gnosticism (2 vols.; ed. B. Layton; SHR, 41; Leiden: Brill, 1981), 2.457-8; G. MacRae, "Seth in Gnostic Texts and Traditions," SBLSP 11 (1977) 24-43; B. Pearson, "The Figure of Seth in Gnostic Literature," The Rediscovery of Gnosticism (2 vols.; ed. B. Layton; SHR, 41; Leiden: Brill, 1981), 2.472-504; M. Stone, "Report on Seth traditions in the Armenian Adam Books," The Rediscovery of Gnosticism (2 vols.; ed. B. Layton; SHR, 41; Leiden: Brill, 1981), 2.459-71.

63 Several additional parallels between 2 Enoch and Melch., which were noticed by Pearson should also be mentioned. According to Pearson's hypothesis in both texts Melchizedek appears in several historical manifestations. Pearson rightly observes that in Slavonic Enoch Melchizedek "has three different manifestations: miraculously born before the Flood, serving in the post-diluvian age as a great priest, and functioning as a priest in the end-time, i.e. in messianic capacity." Birger A. Pearson (ed.), Nag Hammadi Codices IX and X, 30. Pearson also notes that in Melch. Melchizedek appears in several roles: "as ancient priest and recipient of heavenly revelations of the eschatological future, and as eschatological savior-priest identified with permission for this article to be further copied/distributed or hosted elsewhere without the express permission from Brill Academic Publishers. 
Jesus Christ." Birger A. Pearson (ed.), Nag Hammadi Codices IX and X, 20.

According to Pearson, another parallel between 2 Enoch and Melch. is that both texts belong to the genre "apocalypse." Pearson notes that Melch. "satisfies the generic requirements of an apocalypse: it is pseudonymous, attributed to a biblical hero of the past, and contains purported prophecies of future events given by an angelic informant, as well as secrets pertaining to the heavenly world, presumably in a visionary experience." Birger A. Pearson (ed.), Nag Hammadi Codices IX and X, 20.

${ }^{64}$ B. Pearson, "The Figure of Seth in Gnostic Literature," The Rediscovery of Gnosticism, 498.

${ }^{65}$ The question of the relationship between 2 Enoch and the temple in Leontopolis remains open. A possible Alexandrian provenance of Slavonic Enoch could give additional support to this hypothesis. Cf. Fischer, Eschatologie und Jenseitserwartung im hellenistischen Diasporajudentum, 40-41; M. Himmelfarb, Ascent to Heaven in Jewish and Christian Apocalypses (New York/Oxford: Oxford University Press, 1993) 42-5. On the relationship between Leontopolis, Jerusalem, and Qumran see: J. Collins, The Sibylline Oracles of Egyptian Judaism (Missoula: University of Montana, 1974), 48-55; R. Hayward, "The Jewish Temple at Leontopolis: A Reconsideration," JJS 33 (1982) 42943; S. Steckoll, "Qumran Sect in Relation to the Temple of Leontopolis," RevQ 6 (1967) 55-69.

${ }^{66}$ It is interesting to note that the text specifies the place of the future priestly vocation of Melchizedek-"He, Melchizedek will be a priest and a king on the place Achuzan, i.e. the center of the world, where Adam was created." Vaillant, 116. 